SCHOLARS: Journal of Arts \& Humanities Print ISSN: 2773-7829; e-ISSN: 2773-7837

eJournal Site: www.cdetu.edu.np/ejournal/

- Peer-Reviewed, Open Access Journal

- Indexed in NepJOL; Star-Ranked in JPPS

Central Department of English

- Permanently Archived in Portico

Tribhuvan University

Kirtipur, Nepal

URL: www.cdetu.edu.np

Theoretical/Critical Essay Article

DOI: https://doi.org/10.3126/sjah.v4i1.43057

\title{
Reading Polity from the Margin in Arundhati Roy's The Ministry of Utmost Happiness
}

\author{
Binod Aryal \\ Independent Researcher, Besisahar-8, Lamjung, Nepal \\ Corresponding Author: Binod Aryal, Email: binod.aryal6@gmail.com
}

\begin{abstract}
This paper explores the experience and perception of the marginal people and their endeavor to contrive social harmony in the society, eliminating all sorts of discrimination. In this paper, Arundhati Roy's novel The Ministry of Utmost Happiness (2017) has been studied and analyzed to explore this aspect of life in India. To resist the domination of hegemonic power, the dominated people develop a secular living place in the graveyard. The paper uses the theories of subaltern and culture studies to dig out the issues of resistance, subjectivity and agency. The theoretical parameters of Ranajit Guha and Partha Chatterjee have been used to analyze the primary text. The novel presents the biasness of political system that exclude the persecuted group of Indian society. In return, the vulnerable group builds a society in a gloomy and mournful place as a resistance to the supremacy of upper-class Hindus, revealing their subjectivity and agency. This revelation of subjectivity and agency of marginal people critique the polity of the nation in the novel. The finding adds new knowledge to the existing scholarship, departing from other research works.
\end{abstract}

Keywords: Discrimination, subalterns, subjectivity, resistance, marginal

\section{Introduction}

Arundhati Roy's The Ministry of Utmost Happiness presents the audacity of subordinate people to articulate their agency and voice. The novel reveals that after the rise of right-wing Hindu group in the political system, the downtrodden people, religious minorities and social outcaste feel threatened. In addition, the nation treats them as out of social structure preferring the upper Hindu group. They become the subject of domination. The minorities dare to counter vertical social mobility building a dwelling place in tomb, a place for dead. The construction of secular habitat in the burial ground manifests their agency. The spontaneous action of subdued people critiques the limitation of the nation that emerges after the rise of Hindu group in India.

According to the novelist, the Indian society stirs towards the religious nation

Article History:

Submitted 12 November 2021

Revised 25 December 2021

Accepted 19 January 2022

\section{Copyright Information:}

Copyright 2022 (C) The Author(s). The publisher may reuse published articles with prior permission of the concerned author(s). The work is licensed under a Creative Commons Attibution 4.0 International License (CC BY 4.0).

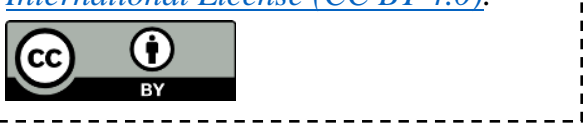

Volume 4, No. 1, February 2022 [pp. 77-86] 
withdrawing the constitutional notion of secularism where a particular religious group covers the political system of the country and shares prejudices and impairments towards other marginal group and ethnicity. The subaltern theorists see the root cause of domination in the historiography of India as it shares the ideology of colonial power. As a resolution of subverting the vertical axis of social mobility, they place a solution of writing the history from the perspective of working class and peasants. The novel deals with the socio-political obstacles of Indian society that pushes the misfits and weirdos to the edge. They are the subject of discrimination and dissidence. Anjum, a subject and a transgender character, develops a living place in the graveyard, which is a place that shelters poor and helpless people in a secular manner. The development of a secular place engulfs their wish to create a secular community revealing their agency. Walter Johnson defines agency as "self-oriented action" (115). Thus, the self-awakening of the character teases the mainstream politics of favoritism.

This study uses the theoretical insight of postcolonial studies, subaltern and cultural studies to produce the contextual knowledge about persons' behavior, social structures and shared belief of a particular group of people of India. To gain better insight of person and social structure, the concept of writing history from the margin developed by Ranajit Guha and Partha Chatterje becomes useful tool to direct the study. Thus, the study aims to dig out the agency of subaltern class that is manifested in the characters' realization, intensification and awakening to bring the positive change in the society.

\section{Limits of Persons: A Critique of Polity}

Roy's The Ministry of Utmost Happiness presents the shattered stories of misfits and weirdoes. The marginal people are suppressed under the socio-political structure of the government guided by the Hindu ideology in the novel. According to the novelist, after the rise of National Democratic Alliance (NDA) led by the right-wing Bharatiya Janata Party (BJP) in the political system, Muslims, Dalits, women and other ethnic minorities are thought to be out of the social structure. India has stood as a federal democratic country in the world with its stratified societies of diverse culture, ethnicity and religions. The novelist believes that a true democratic state ought to accept and tolerate different ideologies. It must accept pluralism and tolerance. The accretion of monolithic vision over governing the nation aggravates the social harmony, which lessens the individual potential, subjectivity and agency. Thus, the literary writings of postcolonial India have become one of the important hidden scenes to reflect the biased policies of the nation that hinders the citizens' potentiality.

The policy of the state impedes the marginal groups to realize the individual power and agency. In this regard, John McLeod articulates the inhuman phenomena about personhood and family members in their postcolonial writings and criticisms of adaptation. The discourse of adaptation is directly adopted from the insights of postcolonial criticism. It often reveals that an identification of the acknowledged persona is not necessarily free and its personhood is not fully a matter of choice as McLeod further argues:

Given the preponderance of these disenfranchising activities across the Commonwealth, it is here that adoption studies and postcolonial inquiry find their first crucial and key point of shared concern: the strategic reshaping of family relations, often requiring the confecting of a child's adoptability or transportability, as one deliberate and central consequence of the advent of colonialism and its legacies around the globe. (208)

With the perspective of adoption theory, McLeod construes that adoption emerges as a painful event that has a direct connection with inequality and exploitation 
resulted from the postcolonial maneuvers of humanitarianism or child rescue. The system provides a sensible and sensitive scenario of moving children through adoption that envisages an index of social and political predicament. In addition, it exposes the colonialism's impact upon appropriation of adoption practices that discrete the family members. The policy of adaptation as a business of colonialism plays a crucial role in separatism and reductionism. As a result, the policy of adaptation downgrades the power of individual and serves the human being as a commodity that lacks self-decision, selfdependency, subjectivity and agency.

In the 1980s, the people blamed the Indian government for the uneven allocation of resources. They alleged the government for the continuation of unjust and prejudice behavior among the citizens of the same nation. In addition, the BJP led government dislocated the marginal people from the mainstream politics, favoring a particular powerful group. As a result, the state could not prolong the economic activities to lowerclass people which, in turn, slows the economic growth of the nation as well. The assembly election held in 1987 raised the hope of amelioration of the nation's condition. However, the previous chaos trend got continued and in turn, it resulted in scarcity and rising prices. In this context, Pradhan H. Prasad writes, the "government policies which have not only perpetuated the very process of uneven regional growth but also have allowed the persistence of the retarded growth syndrome" (225). After the assembly election, the people were optimistic on abstaining the rising prices and poverty in the nation by the ruling parties. But, in regard to people's hope, the government did not formulate the impartial economic distribution through the policies that curbed the uneven dissemination of resources. The absence of government policies for fair destitution forces the poor peasants and working-class people to live in the land of poverty amid of the vast economic prosperity.

India, an emerging economic superpower nation in the world, fails to deliver democratic and constitutional promises. In principle, the federal democratic the subaltern groups do not get their rights, which may carry the hidden possibilities of another social revolution that weakens the foundation of India. In this context, Prabhat Patnaik purviews, "In a society where the people had been passive objects of history, where the village communities contaminated by distinctions of caste and slavery had in Marx's word 'subjugated man to external circumstances instead of elevating man to be the sovereign circumstances"” (6). After it's an economic success, the country envisaged to rise above the identities of caste, religion, region and ethnicity in order to be the part of secular democracy. This raised the hope to all the groups and communities who would be beneficial. However, despite its rapid economic growth, the country could not climb from the narrow domestic walls of fragmentation and poor and under-class people did not benefit from the economic growth. So, Patnaik views that domination and discrimination do not elevate people to their sovereign positions.

The post-colonial theorist Ranajit Guha sees the root cause of oppression in the historiography of India and critiques the nation for upholding the philosophy of colonial ideology. The British colonial and national elite ideologies are manifested in the historiography of India. The theorist believes that India holds the history of elites that excludes and undermines the contribution of peasants and the working-class. Tracing the weaknesses in the historiography of India, Guha sought to situate the subaltern scholar critique of historiography back to the nineteenth century when the Indian intellectuals began debating on the relationship of politics and scholarship. In this regard, he explicitly remarks:

It is the study of this historic failure of the nation to come to its own, a failure due to the inadequacy of the bourgeoisie as well as of the working class to lead it into a 
decisive victory over colonialism and a bourgeois-democratic revolution of either the classic nineteenth-century type under the hegemony of the bourgeoisie or a more modern type under the hegemony of workers and peasants, that is, a 'new democracy' - it is the study of this failure which constitutes the central problematic of the historiography of colonial India. (6)

Guha relates the failure of the nation to the failure of adaptation of writing the history of marginal and downtrodden people. The Indian history acts as the continuation of colonial history adapted by the Indian nationalists and elites. The colonial regime wrote the history from the perspective of the upper-class, which excluded the voice of the peasant movement of the nineteenth and twentieth centuries. At the same time, Guha points out the weaknesses of both bourgeoisies and peasants in the decisive fighting against the colonialism to make the people and nation sovereign. So, he poses the problem in the historiography of India in the creation of a discriminatory society. In order to raise the voice of voiceless, he opines to write the history from the perspective of peasants and working-class people.

Lalita Pandit, on the other hand, explores multiple dimensions of postcolonial theory, culture reading and writing, ideological formation and impact of imperialism in the study of literacy writings. Though the metaphysical sense of postcolonialism imprints an intellectual balance between the contraries like faith and skepticism, hope and despair, she opens a solid structural enclosure of discourse that shows the problems and worries manifested in the postcolonial concept. Expressing her anxieties, she opines, "[F]etishizing of the 'margin' and of 'alterity' as 'a privileged site of intellectual enquiry and political strategy' situates postcolonial discourse within a normative order already established by "hegemonic Western discourses"” (4). According to Pandit, the postcolonial theory subverts the established hierarchies between powerful and powerless. These binaries must be eradicated to create harmony between the margin and the center. In addition, her focus on the issue of 'margin' and 'alterity' in the intellectual and political arena attempts to reverse the concept of western hegemonic discourses.

The postcolonial theory dominates the twenty-first century that deals with questioning the interwoven histories of violence, domination, inequality, prejudices and uneven distribution. It puts its effort to address the cause of domination and oppression of peasants, tribal and indigenous struggles and their relation to colonialism. Concerning the question of existence of postcolonial theory, Robert JC Young argues:

'Post colonialism' is not just a disciplinary field, nor is it a theory which has or has not come to an end. Rather, its objectives have always involved a wide-ranging political project - to reconstruct Western knowledge formations, reorient ethical norms, turn the power structures of the world upside down, refashion the world from below. (20)

Young believes that the theory of postcolonial is dominating and striving. He appends that the theory has never resulted from a singular theoretical formation, but rather from an interconnected set of critical and counter intuitive perspectives and heterogeneous practices that have been evolved out of the traditions of resistance to imperialism and colonialism. He emphasizes on the continuation of the theory as many non-European countries still suffer from the effects of imperial, colonial and neocolonial rule. To analyze such phenomena, it requires shifting conceptualizations. So, Young affirms the existence of the theory to evoke and analyze the indigenous struggles and their relation to colonialism.

There is a debate on the postcolonialism that is interdisciplinary or interdiscursive. In the debate, Malreddy Pavan Kumar argues that there is no single discipline that is better equipped to articulate the social problems. The postcolonial discipline borrows the concepts and critical perspectives from other disciplines as well. 
At the same time, he contemplates that a single discipline is insufficient or inappropriate to describe, expose and overcome the problem of eurocentrism. So, Kumar holds the view that postcolonialism is an interdisciplinary approach. In support of interdisciplinarity of postcolonial study, he writes, "heterogeneous, hybrid and 'locally negotiated syncretic practices that constitute people's lived perceptions of development' are seen as 'emblematic of the coming together of (post) development and post colonialism"' (665). According to Kumar, a single or dominate theory of a discipline cannot expose the real problem of society. In order to read the mosaic and heterogeneity of the society, the theories and critical concepts of different disciplines are required for analysis. An incorporation of heterogeneity view, lived experience and perception of the people helps to define the society and its hegemonic issues.

The knowledge of periphery or margin has occupied prominent space in the human sciences. The space of periphery or margin has attracted various researchers because the facts and data obtained from the marginal sites have helped in the increment of knowledge. The powerful group always rejects the knowledge from the bottom to push them to the edge and to preserve their influence over the vulnerable groups. With respect to this, Ranabir Samaddar opines:

There is one more implication of the postcolonial situation besides the decline of theory, namely, that several distinctions are breaking down.... This is because while the old colonial structure depended on a core-periphery relationship, the new postcolonial structure turns the internal boundaries of this organization into a feature to be constantly, and each time uniquely, negotiated. (42)

The theory of colonialism belongs to the upper-class or superior group as it is fabricated by the colonial power to impose hegemony over the powerless by highlighting their thoughts and knowledge. The theory does not proceed with the date that comes out from the marginal sites. To deliver the knowledge from the periphery, Sarmaddar insists on the subversion of the position of theory. For this, they need their own methods and autonomous space. The methods assemble their new body of knowledge derived from the periphery by erasing the distinction between binary oppositions. In addition, the new methods and autonomous place play a crucial role in eschewing metropolitan thoughts and concepts conveyed through the theoretical perspectives. The researcher claims that the knowledge different from the theory helps to develop ideas and materials from the side of the bottom. So, the postcolonial theory has assisted to blur the distinctions made by the colonial power by breaking down the hierarchies and by putting forth the knowledge from below. So, the colonial theory limits the potential of marginal people by abolishing their voice and knowledge.

In short, the critics and theorists interrogate the monolithic concept and philosophy of a particular religion. Critiquing the domination of a single religion, their works of art re-examine different concepts and practices of social and political intolerance in the democratic and secular societies as toleration is a concept that exclusively opens a liberated space for all the cultural and ethnic groups. The writings of the critics reveal the government's uneven and impartial policies that accumulate an inequitable economic distribution and unjust dissemination of resources. The irrational government policies lead the poor peasants and working-class people and minorities to a destitute position. The processes of alienation and subjugation result in profound animosity, annihilating the individuals' power for a volunteer performance, subjectivity and agency. 
Reading Polity from the Margin in Arundhati Roy's The Ministry 82

\section{Rewriting the Nation}

Roy's The Ministry of Utmost Happiness elicits the issues of struggles and suppression of the minority groups and transgender. The novel also raises the issues of these people's effort to build a secular sanctuary by destablishing the binaries of centreperiphery paradigm as an alternative method of marginal and downtrodden to change the course of national politics. In the novel, Anjum leaves her home and family. She shifts towards the graveyard and fabricates the graveyard as a living place that functions as a multi-faith sanctuary, protecting the people from the tempestuous society by their willpower. The empowerment of characters to build an ideal world for misfits and weirdoes is a motto of the novelist to subvert the existing hierarchies and domination of upper-class Hindus. The exit of Anjum from her house and entry in the transgender society reveals the acceptance of the side of marginal people, rejecting the ordinary social structure of the society that doubts and throws them outside the society. Thus, the novel presents the relentless endeavor of peripheral and misfits in India to build an alternative society to bring the dynamism of downtrodden people in building a harmonious society against the inequitable society.

A nation becomes a nation when it considers all ethnic, religious and cultural groups as equal and creates harmony among the people, embracing them in a single garland of nationalism. Benedict Anderson defines a nation: "It is imagined community, because, regardless of the actual inequality and exploitation that may prevail in each, the nation is always conceived as a deep, horizontal comradeship" (125). Benedict defines a nation as an 'imagined community' that enables the postcolonial societies to contrive the self-image of liberation from imperialist oppression. The unity among diversities, respecting all differences must be a polity of the nation. To subvert the hierarchy prevailing in the nation and to build a harmonious society from the margin, the characters in the novel seek to change the national politics by developing a counter unanimity society. A counter-narrative discourse against the hegemonic discourse of society is an attempt to resist the despotic political system as well. Guided by an interest to advocate on behalf of the lower caste and lower-class people, Roy's novel manifests a persistent interest of the novelist to bring the marginal voices forefront in India and expresses her will to build a venerate society to bring the downtrodden people into the mainstream politics.

Roy's novel narrates the politics of India that has institutionalized the hierarchies and stratification of the society. The novel sheds light on livelihoods, personal safety, spatial arrangements and identity of the marginal people in India. Anjum builds a house in the graveyard and named it "Jannat Paradise" (68). The house stands as a symbol of a dream house for her; she takes it as a place of liberation and self-expression. The paradise starts serving the poor and helpless people. According to the novelist, "Gradually Jannat Guest House becomes a hub for Hijras (transgendered people) who, for one reason or another, had fallen out of, or been expelled from, the tightly administered grid of Hijra Gharanas" (68). The house is "an autonomous domain" as Ranjit Guha argues for it is an effort of the margin to write history from below. Hijras are a marginal group of India who lacks the proper respect and identity in their society. The house provides an opportunity of existence for all who are thrown out of the social structure in any form and accommodates the entire different groups in the garland of unity in the living space.

The novel tailors on how the people even in the reckless social position thrive themselves under a shelter of the graveyard to escort a peaceful life in creating their own way of living, unlike the normative society. Anjum is compelled to unearth a space that confronts the established rules and regulations surveyed by the modern society. This 
subversion helps to empower the subaltern people and deals with them as the subject of the nation rather than objectifying them. The novel posits the "Jannat Guest house began to function as a funeral parlour" (79). The house was built in the graveyard, which is an artistic effort of the novelist to connect the weirdoes and misfits with the aim of restoring the substitute world of margin, lost at the glory of mono-religious Indian social structure. At the same time, the place preserves all the marginal and starts serving the dead bodies of those whom "Duniya had rejected" (80). The people of the house are socially committed to serving humanity and extending their helping hands to the poor and helpless people. Roy deliberately blurs the binary opposition between life and death to focus on the fact that the strength of humanity cannot be exacerbated even in dark situations. This peculiar guest house functions as a miniature that intends a world for the poor and helpless people who exist on the fringes of Indian society.

Roy turns her attention to the abject ambience of the minorities and underprivileged class and people's movements all over India as a new wave of resistance and liberation of the people. For this, she gives her characters the subjectivity and agency that accommodates autonomy and defiance, and that enables them to rewrite the social norms and values. In addition, the novelist empowers women through literature to build their own rules and regulations. According to Oyeronke Oyewumi, "the histories of both the colonized and the colonizer have been written from the male point of view - women are peripheral if they appear at all" (256). The history expresses male centrism as it is written from the male perspective. To come forth, women must challenge the norms and values established by the patriarchal society. As a means to warrant feminism, the novelist presents a rebellious character named Tilo. She kidnaps a baby in Jantar Mantar and runs away from there. The police authority published a notice to return the baby in the newspaper but she refused to return the forsaken baby of Revathy, a moist cadre. It is mentioned in the novel in this way: "When she first read the police notice in the newspaper, Tilo didn't take it seriously...on a second reading, however, she realized it could spell serious trouble" (261). Tilo is a recusant who does not embrace the societal phenomena of relationships, marriage and motherhood. So, being non-conformist, she does not take the first notice seriously, thinking that it may be just a formal notice. But when she reads the second notice, she makes a plan to abscond from the authority rather than to submit the baby. After that, with the assistance of Saddam, she moved to Jannat House. This refusal of obeying the authority is a challenge to establish the social norms. A deprived woman from the essential necessities of family, home and proper upbringing, Tilo emerges as an ardent freedom fighter of Kashmir and turns to be rebellion to fight against the established norms of the society. She challenges the authority by refusing to hand over the child to the police. Her challenge to authority is to make a society for all by destablishing the establishing rules and laws of the society.

At its best, the novel can be phenomenal in its potential to reduce uprising to set up hope for hundreds and thousands of minorities. It deals with how the most under privileged and subdued people manage to retain toehold within the defiant system to create an alternative living. The rebel groups are conducting insurgency in the nation with an aim of inclusiveness that incorporates Muslims, Dalits, insurgents, aboriginals and other minorities in the frame of politics and polity as it is described in the novel:

The government had announced elections in a few months' time. They would be the first in almost nine years. The militants had announced a boycott. It was clear then (unlike now when the queues at the voting booths are unmanageable) that people were not going to come out and vote without some serious persuasion on our part. (171-72)

The election is the beauty of the polity of a democratic nation where people enjoy their freedom of right to choose a national leader on behalf of the people to make 
the national policy, which guarantees the people's development and prosperity. It is believed that the elected members work regardless of any discrimination. However, after the rise of Bharatiya Janta Party (BJP) in political power, the Hindu extremism is burgeoning in India. The rebel group does not want the continuation of the same political system that excludes them. Boycotting the mainstream political election, they want to create a polity where all people can be assimilated into the system.

In addition, thousands of people participate in a hymn, a prayer. The praying aspires the connection to cosmos power. Evoking cosmos power elicits the people's wish against the existing scenario of encroachment of freedom of Kashmiri people. The prevailing political structure presents Kashmir as a war zone. The narrator wishes to turn over the existing social structure and the policy of the authority. The novel puts forth, "I heard the reverberating boom of a hundred thousand or more voices raised together calling for freedom: Azadi! Azadi! Azadi!" (180). Reverberating the freedom by hundreds and thousands of people invokes freedom of the thousands of people who are under suppression and oppression by the mainstream politicians. It is a kind of resistance of federal intervention to the freedom of people and their subjectivity. The novel postulates that the government hates the Kashmiri viscerally and considers them as the citizens of other nations and an object of threat. But the Kashmiri people think that they are part of the nation where the nation treats them as others. So, they pray for freedom and this kind of ritual aims to form a society that accepts the differences among diversities critiquing the Hindu-led government.

Roy dedicated her novel to the 'unconsoled.' The unconsoled are the transgender, Muslim, Dalits and other ethnic minorities. The people are the subdued group marginalized by the social structure. The underprivileged group critiques the polity by cooperating to each other and constructing the dead place as a residential space for them. In this regard "Anjum was waiting for them - an ecstatic smile shining out from among the tombstones" (303). When Saddam drops Tilo to Jannat, Anjum enthusiastically welcomes Tilo and her adopted child. The tombstones are the living place of subdued people, developed by the intersex protagonists. The smile of Anjum in the graveyard, a paradise of misfits, reflects the smile of subdued and underclass people against the cruelty of society. The desolate place, unlike the mainland, accepts happily all the diverse people. This smile contradicts the Indian society that forsakes the underprivileged group from the social mobility. The cooperation and inclusiveness among the marginal people is a way to resist the hegemonic groups and in turn, it is an attempt to create their own kingdom against an outer society that pushes them to the verge of alienation.

Roy originates a web of stories within the novel deeply rooted in disenchantment with the prevailing order that destabilizes the harmony of downtrodden and social outcasts. The novel is an anthem for the despondent and dispossessed group who are squeezed by the social forces. The maltreatment to own citizens as non-citizens circulate the discourse of domination in the society and the discourse governs the social structure, creating a discriminatory environment in the society and country. At the same time, the environment helps to reveal the societal and national structure of polity. As a means of survival in a totalitarian society, the people seek different strategies for living. In the novel, Anjum teaches Gayatri mantra to her daughter to aspire subsistence escaping from the aggressive Hindu mob. At the same time, chanting Gayatri mantra functions as the symbol of tolerance, preservation of differences and respect for another culture. This is the society that the suppressed people want to build a space where everybody has respect and honor for each other. In this respect, a character of the Muslim community, Zainab expresses her wish, "I know a Hindu prayer! Zainab said suddenly. "Shall I recite it here 
in memory of Abbajaan?' Everybody leaned in to listen. And then, sitting at a table in a fast -food restaurant, as a massive of love to her late as well a future-in-law, Zainab recited the Gyatri Mantra that Anjum had taught her when she was a little girl" (412). In an unwelcoming society of India for differences, the novel welcomes the secular position in their marginal society. Unmasking the social and political fault lines of Indian society, the Muslim transgender protagonist Anjum teaches a Hindu-sacred mantra to her adopted daughter Zainab. Though Anjum has taught the mantra to escape from the violence of the Hindu mob at the time of the riot, and later it functions as to respect heterogeneity against homogeneity. Then, in a restaurant, Zainab recites the sacred mantra for her late and future-in-law, which in turn proclaims the latent motif of Anjum to create an ideal society of religious tolerance and inclusiveness.

In the process of rewriting the history from the margin, Roy demonstrates the ideological appropriations of national history that prioritize the rich and upper-class Hindus. To destabilize it, she sets the novel in opposition to the dominant historical narrative that embraces Hinduism in the political system. Not only this, the novel is a critique of Hindu fundamentalist hegemony and seeks to rewrite the history from the margins. Tracing the weakness in the historiography of India, Partha Chatterjee posits, "both colonial and nationalist politics thought of the peasantry as an object of their strategies, to be acted upon, controlled and appropriated within their respective structures of state power" (9). According to Chatterjee, the national politics use the marginal and downtrodden people as an object. The process of objectification kills the agency or subjectivity of the people. So the theorist Chatterjee points out the weakness in the historiography of Indian history as it devoured the agency of underclass people. The Indian society handles the marginal and subordinate people in an ill manner so that they feel difficulty in survival. To countermand the present society as Chatterjee suggests, the people of the bottom imagine two worlds from gazing downward from the flyover. The two worlds symbolize the two separate statuses of the upper-class and lower-class in the same nation. In this regard, the novel posits:

When they took an exist road off it, they saw that underneath the flyover was an entirely different one - an unpaved, unlaned, unlit, unregulated, wild and dangerous one, in which buses, trucks, bullocks riskshaws, cycles, handcarts and pedestrians jostled for survival. One kind of world flew over another kind of world without troubling to stop and ask the time of day. (409)

The novel discloses the novelist's intention to give voice to the voiceless through the construction of a world different from ordinary modern India. When Anjum and her group members drive through the flyover, they saw the underneath path full of disturbance and people rush for survival. The construction of two worlds has a symbolic meaning in the novel. The underneath path shows the modern Indian society covered with negativity suggested through the use of the negative prefix 'un'. On the contrary to the modern society above, it claims an ideal world full of respect, cooperation and honor. The construction of modern society represents India rife with aggressive capitalism, uncaring neo-liberal forces and oppressive social structure. So as an alternative to this, they imagine their own world full of self-esteem.

\section{Conclusion}

Roy's The Ministry of Utmost Happiness is an ode to the social outcaste and under-class people of India, foregrounding perfidy of the nation. The novel deals with the mental ordeal of minorities and exposes how they come together under a single roof, indicating a new political movement that challenges the mainstream politics. The celebration of the creative agency of the marginal people discloses the novelist's 
impeachment to the impartiality of Indian systems and institutions and their adverse consequences to the minorities.

Fostering homogeneity creates a hierarchy among 'us' and 'other,' and in turn creates a stratification of the society to dominate others in the name of the class, caste, or religion. This trait of discrimination is manifested in the modern Indian polity in the novel. To destabilize the vertical axis of social mobility, the marginal people in the society create a linear society where everyone can participate without any biasness. This horizontal social mobility incorporates the notion of humanity and polity to act everyone equally, appreciating unity in diversities. The effort to build an ideal society amid segregation, cooperation and social harmony among them teach a lesson to the government to create a friendly environment reverencing all. At the same time, it critiques the polity of the nation.

\section{Works Cited}

Anderson, Benedict. "Imagined Communities. "The Post-ColonialStudies Reader, edited by Bill Ashcroft et al, Routledge, 2017, pp.123-125.

Armitage, David. "From Colonial History to Postcolonial History: A Turn Too Far?" The William and Mary Quarterly, vol. 64, no.2, April 2007, pp. 251-254.

Chatterjie, Partha. "The Nation and Its Peasants." Mapping the Subaltern studies and the Postcolonial, edited by Vinayak Chaturvedi, Verso, 2000, pp. 8 -23.

Guha, Ranajit. "On Some Aspects of the Historiography of Colonial India." Mapping the Subaltern studies and the Postcolonial, edited by Vinayak Chaturvedi, Verso, 2000, pp. 1-7.

Johnson, Walter. "On Agency." Journal of Social History, vol. 37, no. 1, Autumn, 2003, pp. 113-124.

Kumar, Malreddy Pavan. "Postcolonialism: Interdisciplinary or Interdiscursive?" Third World Quarterly, vol. 32, no. 4, 2011, pp. 653-672.

McLeod, John. "Adoption Studies and Postcolonial Inquiry." Critical Adoption Studies, vol. 6, no. 1, 2008, pp. 206-228.

Oyeronke, Oyewumi. "Colonizing Bodies and Minds." The Post-Colonial Studies Reader, edited by Bill Ashcroft et al, Routledge, 2017, pp. 256-259.

Pandit, Lalita. "Introduction: Local, Global, Postcolonial Author(s)." College Literature, vol. 19/20 no. 3/1, October 1992 and February 1993, pp. 1-6.

Patnaik, Prabhat. "Independent India at Sixty-Five." Social Scientist, vol. 41, no. 1/2, January-February 2013, pp. 5-15.

Prasad, Pradhan H. "Economic Roots of Political Struggle in Independent India." Economic and Political Weekly, vol. 26, no.5, 2 Feb. 1991, pp. 225-228.

Roy, Arundhati. The Ministry of Utmost Happiness. Knopf, 2017.

Samaddar, Ranabir. "What Is Postcolonial Predicament?" Economic and Political Weekly, vol. 47, no. 9, 3 March 2012, pp. 41-50.

Young, Robert JC. "Postcolonial Remains" New Literary History, vol. 43, no. 1, 2012, pp. 19-42.

\section{To cite this article [MLA style]:}

Aryal, Binod. "Reading Polity from the margin in Arundhati Roy's The Ministry of Utmost Happiness." SCHOLARS: Journal of Arts \& Humanities, vol. 4, no. 1, February 2022, pp. 77-86. NepJOL, doi:10.3126/sjah.v4i1.43057. 